\title{
O Centro de Turismo de Natal (RN, Brasil): subsídios para o estudo do centro histórico
}

\author{
Fernando Manuel Rocha da Cruz* \\ CRIA - Centro em Rede de Investigação em Antropologia (Portugal)
}

\begin{abstract}
Resumo: Natal, capital do estado brasileiro do Rio Grande do Norte, recebe anualmente dois milhões de turistas, sobretudo do segmento sol e mar. O seu centro histórico foi classificado pelo Iphan como património cultural brasileiro, em 2010. Procuramos, no presente artigo, identificar as potencialidades e fraquezas do turismo cultural, a partir do centro histórico de Natal. Para tanto, levamos a cabo um estudo de caso, a partir do Centro de Turismo, o qual se encontra localizado no referido centro histórico. Neste contexto, foram aplicadas entrevistas semiestruturadas a empresários, secretários de turismo - municipal e estadual - e turistas. Concluímos que, apesar de alguns avanços, o centro histórico permanece numa posição secundária nas opções políticas e económicas. Para além disso, a triangulação da cultura, turismo e políticas públicas de Natal permitem identificar competências positivas e negativas que possibilitam caracterizar a situação atual do turismo cultural na cidade.
\end{abstract}

Palavras-chave: Centro histórico; Indústrias culturais e criativas; Património cultural; Natal (Brasil); Turismo cultural.

The Natal Tourism Centre (RN, Brazil): subsidies for the study of the historic centre

Abstract: Natal, capital of the Brazilian state of Rio Grande do Norte, annually receives two million tourists, mainly from the sun and beach segment. Its historic centre was classified by Iphan as a Brazilian cultural heritage in 2010. In this article, we seek to identify the potential and weaknesses of cultural tourism, starting from the historic centre of Natal. To this end, we carried out a case study, from the Tourism Centre, which is located in the aforementioned historic centre. In this context, semi-structured interviews were applied to businessmen, tourism secretaries - municipal and state - and tourists. We conclude that, despite some advances, the historic centre remains in a secondary position in political and economic options. In addition, the triangulation of Natal's culture, tourism and public policies allows the identification of positive and negative skills that make it possible to characterize the current situation of cultural tourism in the city.

Keywords: Historical centre; Creative industries; Cultural heritage; Cultural tourism; Natal (Brazil).

\section{Introdução}

A cidade de Natal é a capital do estado do Rio Grande do Norte (RN), no nordeste brasileiro. Trata-se de um destino turístico privilegiado no segmento de sol e mar devido ao clima e às suas praias. Atualmente, é uma cidade que depende em termos económicos do setor público e do turismo e a sua população está estimada em 877.640 habitantes (Ibge, 2019). Em 2017, o aeroporto de São Gonçalo do Amarante, na Região Metropolitana de Natal recebeu mais de 2,4 milhões de passageiros, registando um aumento de 87,2 mil passageiros em relação ao ano anterior (Rocha, 2018). A maioria dos turistas são brasileiros e quanto a turistas estrangeiros destacam-se os argentinos (25,9\%, em 2018), enquanto portugueses, italianos, chilenos, uruguaios e paraguaios registaram valores entre $0,2 \%$ e $0,7 \%$, em 2018 , por nacionalidade (Ipdc, 2018).

Em 2010, o centro histórico de Natal foi qualificado pelo Instituto do Património Histórico e Artístico Nacional (Iphan), em virtude do seu valor arquitetónico, urbanístico e paisagístico (Costa y Amaral, 2014). Segundo o Iphan (2010: sp), o centro histórico de Natal "mescla uma malha urbana colonial com um conjunto arquitetônico de todas as épocas, mas em que o século XX deixou a sua maior marca".

CRIA - Centro em Rede de Investigação em Antropologia (Portugal); -mail: fmrcruz@gmail.com; https://orcid.org/0000$-0002-1254-5601$ 
O mesmo Instituto chama a atenção, relativamente ao centro histórico, para "a área que deu início à cidade ainda conserva[r] conjuntos de edifícios e bairros com suficiente representatividade histórica, justificando o de sua preservação como patrimônio cultural brasileiro" (Iphan, 2010: sp).

No entanto, o centro histórico é desconhecido por muitos natalenses por não conseguirem estabelecer relações de afetividade, identidade ou pertencimento com essa parte da cidade. O distanciamento da população dificulta, por conseguinte, a preservação da parte mais antiga da cidade. Acresce ainda a fraca presença de turistas nessa área urbana por falta de informação, falta de preparação da viagem (Costa y Amaral, 2014), ou ainda pela insegurança urbana (Cruz, 2018).

Este artigo tem por objetivos caracterizar o turismo no Centro de Turismo de Natal e identificar potencialidades e fragilidades do turismo no centro histórico de Natal, bem como propor um modelo de estudo do turismo cultural de centros históricos, tendo em vista permitir a sua comparabilidade de forma a permitir subsidiar planos de desenvolvimento de turismo cultural. Para o efeito, em termos metodológicos, partimos do estudo de caso enquanto investigação exploratória, uma vez que procuramos nos familiarizar com o objeto da pesquisa. Quanto à abordagem é uma pesquisa qualitativa que visa aprofundar o conhecimento sobre o referido objeto e que, por isso, não possui qualquer intuito de generalização dos seus resultados. Desse modo, as principais técnicas de pesquisa utilizadas foram a observação direta e as entrevistas semiestruturadas a empresários e/ou vendedores, turistas e representantes políticos da área turística.

Em relação à estrutura do artigo, começamos por abordar os principais conceitos e desenvolvimentos teóricos sobre o património cultural e o turismo cultural. Na segunda parte, caracterizamos as principais opções metodológicas seguidas na investigação, para encerrarmos com a apresentação dos resultados da pesquisa empírica sobre o Centro de Turismo e o centro histórico de Natal.

\section{Património cultural}

Património, cultura e turismo são campos que respondem ao desafio da interdisciplinaridade, sendo por conseguinte necessário construir pontes entre as especificidades do olhar disciplinar e as apropriações de instrumentos teóricos e metodológicos de identificação e gestão patrimoniais (Chuva y Nogueira, 2012; Nogueira, 2014). O campo implica a existência de lógicas de constituição com regras próprias, valores e diferenciações específicas com disputas simbólicas entre classes e grupos sociais para a construção de representações sociais e versões hegemónicas das experiências histórico-culturais (Bourdieu, 1989; Nogueira, 2014). Após a Segunda Guerra Mundial, foram criados 95\% dos museus e milhares de sítios históricos, como consequência da influência "universalizante" da Organização das Nações Unidas para a Educação, a Ciência e a Cultura (UNESCO). Desse modo, o património passou a ser visto nas cidades como fator de desenvolvimento. (Tamaso, 2005). Assim, os centros históricos foram patrimonializados enquanto as populações os abandonavam, procurando melhores condições de vida nos novos bairros urbanos, como aconteceu na cidade de Natal.

Acresce que, a memória é um mecanismo complexo de legitimação das opções sociais e dos diferentes grupos socioculturais. Desse modo, é um instrumento estruturador de identidades e um mecanismo ideológico de compensação face às perdas ou fraquezas de um grupo ou sociedade. Por consequência, a memória coletiva é uma máscara identitária que se apoia no património cultural (Oosterbeek, 2015), a qual se opera de forma coerente - e não histórica - na reconstrução do passado e, tendo em conta, as exigências ideológicas do seu tempo e a união da sociedade como um todo (Halbwachs, 1990; 1994).

Tamaso (2005), por seu lado, chama a atenção para a noção de legado universal que no seu entendimento limita a posse do património material a alguns - classes altas e entes políticos do Estado - enquanto as classes médias e baixas são excluídas desse direito de propriedade. Porém, relativamente ao património imaterial, verificamos que este é ainda um direito de propriedade da classe social que o produz, como é o caso do artesanato. No entanto, questionamos esse controlo perpetuado desde o passado com a crescente monopolização pelas entidades políticas do Estado relativamente aos modos de criação, produção, distribuição e mercado como, por exemplo, do artesanato no estado do Rio Grande do Norte, uma vez que aparece a definir os locais em que podem ser comercializados, bem como, através da formação profissional, a influir nos processos de criação e produção artesanal.

O património cultural traduz-se assim na representação simbólica da cultura e, designadamente dos processos de seleção, negociação e circunscrição dos significados. Consequentemente, no conceito de património cultural está subjacente a forma como se manifesta a representação da cultura, quer através da promoção da conservação, quer da revalorização dos elementos culturais. Contudo, existe a consciência que não é possível conservar ou patrimonializar toda a cultura (Pereiro, 2003). 
A propósito e, atenta a complexidade diacrónica e sincrónica do termo "cultura", Williams (2000) destaca neste uma tripla dimensão: estado ou processo de perfeição humana (ideal); corpo material que resulta da produção do pensamento e experiência humana (documentação); e, estilos de vida articulados com valores, significados e instituições (modos de vida). Por sua vez, Eagleton (2003) entende que o capitalismo transnacional explica a crise identitária (e cultural) dos indivíduos. Paralelamente, deixamos de falar em Cultura para preferirmos a palavra "culturas" (e subculturas) para expressarmos "universalismos concretos", do ponto de vista pós-moderno (Eagleton, 2003: 61). Cabe ainda, atender à proposta de Geertz (2008) que define cultura como:

sendo essas teias e a sua análise; portanto, não como uma ciência experimental em busca de leis, mas como uma ciência interpretativa, à procura do significado. É justamente uma explicação que eu procuro, ao construir expressões sociais enigmáticas na sua superfície (Geertz, 2008: 4).

Importa ainda considerar o conceito de cultura como recurso. Para Yúdice (2004), há que atender à sua gestão visto que este recurso circula globalmente e a um ritmo crescente. A cultura transnacional é, por conseguinte, utilizada nas indústrias de entretenimento e na sociedade civil como as Organizações não-governamentais transnacionais. Nesta perspetiva, subsistem diferenças regionais e nacionais neste recurso, o qual é visto a partir da sua funcionalidade para o comércio e ativismo globais.

No presente artigo, importa-nos quer a cultura como recurso, quer a cultura enquanto prática e representação social, cultural e histórica aplicada quer ao simbolismo do edifício histórico do Centro de Turismo de Natal, bem como à produção artesanal vendida no mesmo imóvel. Neste último sentido, Maffesoli (2012) corrobora que não é apenas o tempo que cria o passado, mas também o espaço. As relações sociais se enraízam no tempo e no espaço e, estão presentes em todas as manifestações que celebram o lugar, o folclore e as tradições, fatos e personalidades locais.

Consequentemente, o significado do património depende da posição e do momento de quem atribui esse simbolismo, estando essa construção histórica e cultural sujeita a contingências espaciais e temporais (Sousa, Netto y Oliveira, 2019). Ao atribuirmos valores, sejam eles, históricos, sociais ou estéticos, ao espaço urbano, como é o caso do centro histórico de Natal, passa a ser entendido como património cultural. Por outro lado, resultam das políticas urbanas elevados investimentos públicos e privados, através de ações e intervenções urbanísticas que têm por consequência a intensificação dos processos de patrimonialização das cidades. Tais ações exploram a inclusão desses espaços na dinâmica urbana, através da espetacularização da cidade e da sua inclusão nos circuitos económicos e turísticos (Oliveira, 2016; Cruz, 2011).

A Constituição Federal brasileira de 1988 estatui no seu artigo 216 que o património cultural é constituído por "bens de natureza material e imaterial, tomados individualmente ou em conjunto, portadores de referência à identidade, à ação, à memória dos diferentes grupos formadores da sociedade brasileira" (Brasil, 1988). Desse modo, o campo de atuação da proteção do património cultural, sob tutela jurídica, abrange não somente os bens materiais, mas também os bens imateriais como por exemplo tradições, folclore, saberes, línguas, festas e manifestações populares (Sousa, Netto y Oliveira, 2019). Nesse sentido, Pereiro (2009) atribui ao património cultural um sentido público, comunitário e de identificação coletiva alargada.

Nas últimas décadas, o conceito de património cultural deslocou-se progressivamente do âmbito dos monumentos e sítios para o âmbito das paisagens culturais, procurando, por conseguinte, albergar a crescente variedade e divergência de interesses socioculturais. Nesse sentido, em 1972, nasce a ideia de um património mundial da Humanidade, "com esse propósito globalizador e pacificador, combinando as preocupações de preservação que haviam emergido no quadro da Segunda Guerra Mundial com as novas inquietações sobre o meio ambiente e a lógica inelutável da globalização" (Oosterbeek, 2015: 17).

A Convenção para a Proteção do Património Mundial, Cultural e Natural (Unesco, 1972) considera, enquanto princípio indiscutível, que todo o património, independentemente da sua localização, deve ser considerado herança da humanidade. Dümcke e Gnedovsky (2013) apontam que o património cultural é constituído por atividades especializadas que envolvem o património bem como outras relacionadas com setores sociais ou económicos. Desse modo, distinguem:

a) Património cultural como um setor de atividades que proporciona emprego e crescimento geral;

b) Repercussões sociais e económicas do património cultural em outros domínios como, por exemplo, agricultura, desenvolvimento regional, ambiente, ciência, educação, turismo, tecnologia, inovação, coesão social e diálogo intercultural. 
O setor do património é uma das indústrias culturais e criativas (ICCs) onde se deve enfatizar o seu ciclo económico, mas também os efeitos indiretos em outros setores (Dümcke y Gnedovsky, 2013; Cruz, 2016). Assim, as ICCs, ou seja, os empreendimentos que têm por objeto a cultura, a arte ou o património e que nas diferentes fases do seu ciclo económico têm por objetivo o lucro, foram institucionalizadas no Brasil, em 2012, com a criação da Secretaria da Economia Criativa, sob dependência do Ministério da Cultura (Cruz, 2019). Nesse sentido, verificamos uma alteração de paradigma na oferta de produtos e serviços culturais, artísticos e patrimoniais, muito mais economicista que importa ter em atenção no presente estudo e que vai de encontro ao conceito de cultura como recurso de Yúdice (2004).

\section{Turismo cultural}

A perspetiva de desenvolvimento do turismo cultural levou à adaptação para fins turísticos da maioria das cidades com edificações históricas. Desse modo, essas cidades apropriaram-se desse património para o transformar em produto turístico. Por um lado, o património permite a criação e desenvolvimento de itinerários turísticos e culturais, bem como, a valorização e a revitalização de ofertas pré-existentes. Por outro lado, o turismo tornou-se um instrumento de apoio à reabilitação do património em cidades históricas (Marujo, Serra y Borges, 2013).

Para Richards (2009), o turismo cultural é a área de maior crescimento no turismo global e a maior área de desenvolvimento de produto dos destinos turísticos na procura de diversificação. Trata-se de uma opção atrativa visto que corresponde ao desejo de "turismo de qualidade", à necessidade de encontrar recursos para apoiar a cultura local e a imediata disponibilidade dos recursos culturais. Daí que, o património cultural seja percebido atualmente como fonte de conhecimento e de rentabilidade económica, a partir do turismo e da contribuição dos recursos culturais no âmbito do desenvolvimento sociocultural da comunidade local e da sua relação com o referido setor (Morais, 2012).

Köhler e Durand (2007) distinguiram dois tipos conceituais de turismo cultural. Por um lado, o turismo cultural pode ser entendido a partir da demanda, ou seja, a partir das motivações, perceções e experiências pessoais das viagens. Neste caso, são privilegiadas as interpretações individuais sobre as experiências turísticas, as quais são classificadas como culturais, de acordo com a interpretação subjetiva do turista. Nesta aceção podemos colocar em dúvida a fiabilidade da interpretação psicológica sobre o que é atração cultural. No segundo tipo conceitual, é defendido que o turismo cultural diz respeito à oferta e se baseia na fruição turística de equipamentos e atrações previamente classificadas como culturais como é o caso dos sítios e centros históricos, festivais, gastronomia local, centros de interpretação patrimonial, mercados tradicionais, museus, para além de outros espaços, objetos e eventos (Köhler y Durand, 2007). É, nesta segunda aceção, que privilegiamos o estudo centrado no Centro de Turismo de Natal.

Igualmente, McKercher e Du Cros (2003) definem turismo cultural como o consumo turístico de atrações turísticas previamente classificadas como culturais. Segundo Köhler e Durand (2007), trata-se de uma definição que faz uma delimitação razoável do segmento do mercado turístico, atendendo aos elementos tangíveis e intangíveis que podem ser classificados como património cultural; que admite a análise de fatores como grandeza, padrões da visita e gastos no destino; e que, por fim, possibilita a expansão dos objetos alvo do olhar do turista, bem como o consumo de experiências diferenciadas.

Quanto aos locais de destino turístico, não devemos esquecer que as culturas recetoras de turismo desenvolvem sistemas de hospitalidade que adaptam aos visitantes, consciente ou inconscientemente, por meio de estereótipos (Pereiro, 2009). Paralelamente, a indústria turística e os próprios turistas criam estereótipos sobre essas culturas recetoras. De fato, o turismo pode ser entendido como um ritual de passagem, de renascimento ou mudança que marca a distinção entre o tempo de lazer e o tempo do trabalho. Martins (2013) funda o lazer no tempo dedicado ao descanso - que se contrapõe ao tempo do trabalho -, ao desenvolvimento da personalidade e à diversão. Este tem um caráter libertador por resultar da livre escolha do indivíduo ainda que existam condicionalismos socioeconómicos. Aliberdade que se trata aqui, é sobretudo, a do tempo que não é dedicado ao trabalho. Neste inclui-se o tempo dedicado ao turismo, mas que implica a satisfação de pressupostos socioeconómicos. Aqui, não nos parece que atividades de city tour, destinadas essencialmente ao turismo de massa, favoreçam o ócio enquanto valorização pessoal e sociocultural, devido à escassez de tempo dedicado a cada ponto turístico, nomeadamente do Centro de Turismo e ao centro histórico de Natal, como veremos.

Ainda que a procura do autêntico seja uma das explicações para a organização do turismo, Urry e Larsen (2011) não concordam com esta possibilidade, sugerindo como explicação a diferença do olhar entre o local do turismo e o da residência ou do trabalho. Mas esse olhar do turista envolve a deslocação 
corpórea do turista e o encontro de uma comunidade local recetora, assim como um mundo físico multissensorial. Neste olhar e movimento, incluímos diferentes formas de prazer (Urry y Larsen, 2011).

O turismo pode ainda ser perspetivado como promotor de diferenciação social, uma vez que dá lugar à produção e ao consumo de bens simbólicos. Desse modo, segundo Pereiro (2009), a prática turística é uma expressão da identidade social. Igualmente Bourdieu (2007), referindo-se à estilização da vida em que a forma (estética) tem o primado sobre a função (ética), considera que as condições sociais e económicas distintas explicam as diferentes posições no espaço social, as quais estão relacionadas com os sistemas de disposições (habitus) característicos das diferentes classes e subclasses. Urry e Larsen (2011) entendem que o olhar é, por isso, enformado pelas ideias, habilidades, desejos e expectativas variando em termos de classe social, género, nacionalidade, idade ou escolaridade. Este olhar, para além de provocar a reflexão, ordena, modela e classifica o mundo. Para estes autores, ser turista é uma característica definidora do ser "moderno" resultante do trabalho remunerado. Esse tempo é passado em determinados lugares e verifica-se em períodos de tempo regulares. Por conseguinte, o desenvolvimento do turismo cultural e a crescente procura têm como fatores: o aumento da escolaridade, do rendimento e das novas tecnologias de informação e comunicação, assim como, do crescente papel da mulher na economia e de uma maior consciência da globalização (Richards, 2007; Marujo, Serra y Borges, 2013).

Quanto às motivações dos turistas culturais em cidades históricas, Jansen-Verbeke (1997) distinguem três tipos:

a) Turistas de motivação cultural - são aqueles que selecionam o destino em função das características culturais do lugar;

b) Turistas de inspiração cultural - são atraídos pelas manifestações culturais específicas;

c) Turistas atraídos pela cultura - são aqueles que aproveitam maximizar as experiências culturais do lugar, embora este não tenha sido selecionado pelo fator cultural.

No estudo em apreço, apenas conseguimos identificar turistas de inspiração cultural no Centro de Turismo e, consequentemente no centro histórico de Natal, que não escolheram o local pelo fator cultural, mas que terminam por ser aliciados para manifestações culturais particulares.

\section{A estratégia metodológica}

Em termos metodológicos, optamos, ao nível da abordagem do problema, por uma pesquisa qualitativa que entendemos ser a mais adequada em termos de análise e profundidade do objeto em estudo. Esta permite explorar e compreender o significado que indivíduos ou grupos conferem a um problema social. É, por isso, uma investigação que privilegia um estilo indutivo, o significado individual e a complexidade da situação (Creswell, 2009). Nesse sentido, a metodologia qualitativa procura documentar o que as pessoas dizem e pensam sobre os fenómenos sociais, captando a riqueza e a diversidade de significados. Assim, é importante captar a fragilidade do mundo social e nos termos em que é criada (Holdaway, 2000). Trata-se também de um tipo de procedimento lógico de investigação empírica - a análise intensiva - que procura compreender o fenómeno na sua globalidade. A este método são apontadas três características: intensidade, flexibilidade do método e análise e relacionamento dos dados (Almeida y Pinto, 1995)

Do ponto de vista da natureza, é uma investigação básica que procura gerar conhecimentos novos e relevantes, mas que não possui um intuito imediato de aplicação prática. Quanto aos seus objetivos, podemos classificar a pesquisa de exploratória pois visa obter mais informações sobre o objeto de pesquisa enquanto do ponto de vista dos procedimentos técnicos é uma pesquisa de campo que tem por objetivo conseguir informações que subsidiem o estudo e dar resposta ao problema científico subjacente (Prodanov y Freitas, 2013). Esta pesquisa não tem, por conseguinte, qualquer objetivo em termos de generalização por se caracterizar como estudo de caso (Yin, 2005).

Neste âmbito, a entrevista constitui-se como uma dos principais técnicas de recolha de informação utilizada e que nos encontramos a apresentar. Recorremos ao tipo de entrevista semiestruturada por entendermos que é aquela que definindo previamente um roteiro de entrevista, privilegia a posteriori a comparação entre as questões com a identificação dos aspetos comuns e dissemelhantes. Esta não impede a colocação de novas questões no decorrer da entrevista, tendo em vista o aprofundamento das respostas. É também uma entrevista centrada que permite obter informação do entrevistado ao explicitar as suas impressões acerca dos fenómenos sociais, tornando essa informação generalizável (Almeida y Pinto, 1995; Cruz, 2019). Na presente pesquisa, foram entrevistados quatro empresários/vendedores do Centro de Turismo de Natal e os secretários de turismo 
do Governo do Estado do Rio Grande do Norte e da Prefeitura de Natal. Subsidiariamente, foram ainda entrevistados seis turistas e informalmente outros dez de visita ao Centro de Turismo para confrontarmos sobretudo com as informações obtidas através do primeiro grupo de entrevistados. Atentos os objetivos da investigação, quer empresários/vendedores, quer secretários de turismo foram selecionados devido à sua implicação direta com o Centro de Turismo e a área governativa (local e estadual).

As entrevistas foram objeto de análise de conteúdo, a qual é definida por Rada (2005) como o conjunto de técnicas de análise que têm por objeto as classes ou categorias de "texto", ou seja, as formas intencionais e expressivas de comunicação intersubjetiva. Desse modo, a análise de conteúdo procurou objetivar o tema em análise, através da identificação das unidades de análise que são os elementos que possibilitam a codificação e a categorização (Romero, 1991). Ora, proceder à análise temática é descobrir os "núcleos de sentido" que compõem a comunicação. Assim, o tema, enquanto unidade de registo, corresponde a uma regra de recorte do sentido que não é facultada de uma só vez, já que depende do seu nível de análise (Bardin, 2008: 131).

As unidades de análise, sobre as quais incidiram as entrevistas foram as seguintes: centro histórico de Natal; roteiro turístico do city tour; experiência turística em Natal; Centro de Turismo; agências de viagem e de turismo recetivo; poderes públicos.

\section{Centro histórico de Natal}

\subsection{Centro de Turismo}

O centro histórico de Natal localiza-se no bairro da Cidade Alta e ocupa ainda uma parte do bairro da Ribeira. Foi qualificado de interesse nacional pelo Iphan, em 2010, devido ao seu "conjunto arquitetônico, urbanístico e paisagístico", onde se destacam:

- Forte dos Reis Magos,

- Igreja de Santo António,

- Igreja de Nossa Senhora do Rosário dos Pretos,

- Palácio Potengi (atual Pinacoteca do Estado/Palácio da Cultura),

- Véu da Noiva ou Sobradinho,

- Armazém Real da Capitania (atual Superintendência do Iphan no Rio Grande do Norte),

- Prefeitura Municipal de Natal (Palácio Felipe Camarão),

- Centro de Turismo de Natal,

- Teatro Carlos Gomes (atual Teatro Alberto Maranhão),

- Antigo Liceu Industrial (atual Instituto Federal de Ciência Educação e Tecnologia do Rio Grande do Norte),

- Instituto Histórico e Geográfico do Rio Grande do Norte,

- Museu Café Filho,

- Marco de Touros (marco Quinhentista) (Iphan, 2018).

Quanto ao Centro de Turismo, este possui uma elevada relevância em termos patrimoniais e de turismo cultural, razão pela qual, optamos por desenvolver a nossa pesquisa, a partir deste ícone patrimonial. Este foi construído no final do século XIX e serviu inicialmente de casa de veraneio. Em 1911, passou a Asilo de mendigos Padre João Maria e em 1920, a Orfanato feminino. Em 1943, passou à gestão do governo federal brasileiro, para ser utilizado como base de apoio à participação dos americanos na Segunda Guerra Mundial. Em 1945, foi reformado e usado como Casa de Detenção. Já, em 1976, após a recuperação da sua estrutura, começou a funcionar como Centro de Turismo. Por fim, em 1988, foi qualificado como património histórico de interesse estadual (Natal, 2008; Tribuna do Norte, 2016). Possui uma arquitetura neoclássica e fica localizado na colina do bairro de Petrópolis, na cidade de Natal. Os seus 40 empreendimentos geram cerca de 100 empregos distribuídos por restaurante, lojas de artesanato, galeria de arte, antiquário, bar e administração. Do edifício, é possível apreciar paisagens sobre a cidade, o rio Potengi e a ponte Newton Navarro. As lojas de artesanato estão localizadas em celas da antiga Casa de Detenção, nas quais foram mantidas as grades de ferro nas janelas (Tribuna do Norte, 2016). O prédio é da propriedade do Estado do Rio Grande do Norte e gerido pela Associação dos Empreendedores do Centro de Turismo de Natal - ASSECTUR.

\subsection{Centro de Turismo}

Segundo dados da ASSECTUR, em 2018, visitaram o imóvel 114.367 turistas, dos quais, a maior afluência foi registada em dezembro com 15.230 visitantes e a menor em junho (5426 visitantes). Este registo apenas considera os turistas que chegaram através dos autocarros das Agências de turismo, turismo recetivo ou táxis (ver Quadro 1). 
Quadro 1: Visitantes do Centro de Turismo de Natal (2018)

\begin{tabular}{|l|c|c|c|}
\hline \multicolumn{1}{|c|}{ Mês } & $\begin{array}{c}\text { Agências de Viagens/ } \\
\text { Recetivo }\end{array}$ & Táxis & Total \\
\hline Janeiro & 12208 & 279 & $\mathbf{1 2 4 8 7}$ \\
\hline Fevereiro & 9068 & 234 & $\mathbf{9 3 0 2}$ \\
\hline Março & 9195 & 119 & $\mathbf{9 3 1 4}$ \\
\hline Abril & 8457 & 159 & $\mathbf{8 6 1 6}$ \\
\hline Maio & 6833 & 153 & $\mathbf{6 9 8 6}$ \\
\hline Junho & 5320 & 106 & $\mathbf{5 4 2 6}$ \\
\hline Julho & 9208 & 223 & $\mathbf{9 4 3 1}$ \\
\hline Agosto & 8662 & 134 & $\mathbf{8 7 9 6}$ \\
\hline Setembro & 8113 & 245 & $\mathbf{8 3 5 8}$ \\
\hline Outubro & 9796 & 187 & $\mathbf{1 0 4 3 8}$ \\
\hline Novembro & 10201 & 237 & $\mathbf{1 5 2 3 0}$ \\
\hline Dezembro & 15122 & 108 & $\mathbf{1 1 4 3 6 7}$ \\
\hline \multicolumn{2}{|c|}{ Total } & $\mathbf{1 1 2 1 8 3}$ & $\mathbf{2 1 8 4}$ \\
\hline
\end{tabular}

Fonte: ASSECTUR (2018)

\subsubsection{Representações sociais dos empresários/vendedores}

O conhecimento do centro histórico de Natal por parte dos quatro empresários/vendedores entrevistados do Centro de Turismo (ver Figura 1) é, na maioria dos casos, superficial, geográfico e limitado ao exterior de alguns edifícios. Destes, Francisco Albuquerque e Jailde Melo são aqueles que demonstram um maior conhecimento. Porém, todos eles acabam por ser demandados para dar informações sobre o referido centro histórico e, em particular, o Centro de Turismo.

Figura 1: Nível de conhecimento dos empresários/ vendedores sobre centro histórico de Natal

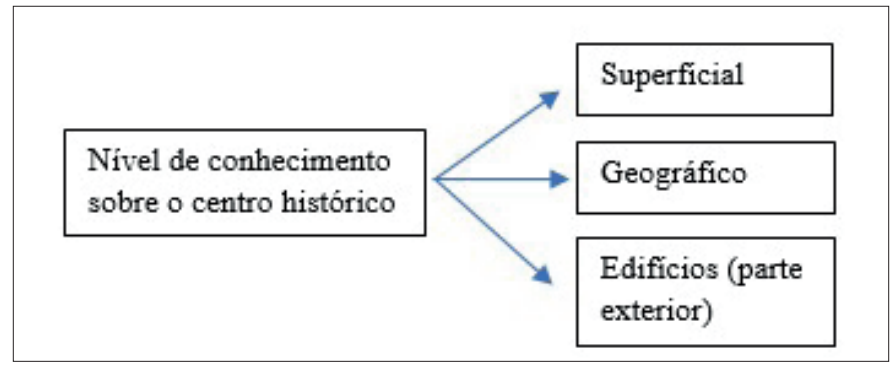

Fonte: Elaboração própria.

Entre 1986 e 2000, apesar do Centro de Turismo já estar qualificado como património de interesse estadual e ser da propriedade do Estado do Rio Grande do Norte, foi necessário, de acordo com Francisco Albuquerque, criar uma comissão interna para evitar a sua degradação. Assim, foi negociada uma parceria público-privada com o Governo do Estado, nomeadamente com a Governadora Wilma de Faria, para a cedência da preservação e gestão do mesmo. Por isso, a ASSECTUR (ver Figura 2) foi criada com a finalidade de gerir este património cultural. Nesse intuito, as rendas das lojas revertem para o pagamento da sua manutenção e preservação e apenas recentemente foi contratada a sua divulgação nas redes sociais. A administração do património cultural por uma associação privada tem como principal vantagem evitar a sua deterioração. Contudo, não permite a realização de melhoramentos e tem em 
vista apenas a utilização do espaço pelas atividades económicas e culturais aí desenvolvidas. Em termos patrimoniais, podemos salientar a complementaridade de duas vertentes: o edifício como património material e o artesanato, a gastronomia e o forró enquanto património imaterial, encontrando-se a primeira subordinada à segunda vertente.

Figura 2: Centro de Turismo

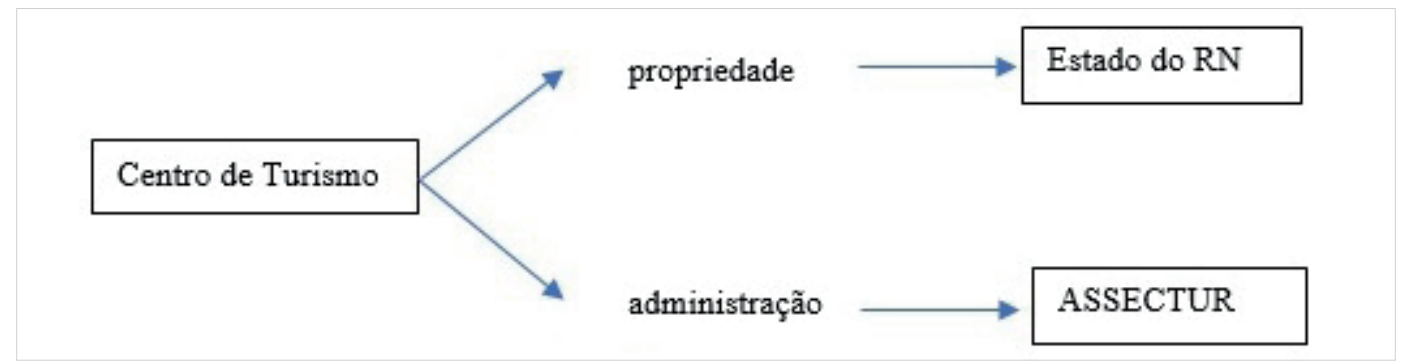

Fonte: Elaboração própria.

O Centro de Turismo possui, segundo Francisco Albuquerque, uma grande projeção com a organização do "Forró com turista". A sua divulgação passa pelas redes sociais, bem como junto das agências de turismo recetivo. Esta atividade foi criada em 1987 e, desde então, os próprios clientes contribuem para a divulgação da mesma junto de outros interessados. Os turistas chegam pelas $21 \mathrm{~h} 00$ e ficam até à meia-noite. Durante esse período, podem visitar as lojas abertas e existem agentes de segurança quer no interior, quer no exterior. A sua longevidade contribui para esse conhecimento quer junto dos agentes turísticos quer dos próprios turistas. A divulgação é feita de modo tradicional com folhetos junto dos agentes de turismo, hotéis e restaurantes sobretudo da zona sul da cidade, mas também na internet através de uma página web.

Contudo, todos os empresários/vendedores consideram faltar a divulgação do Centro de Turismo, por parte das entidades públicas (ver Figura 3). Na opinião de Francisco Albuquerque, o Centro de Turismo precisa apostar diariamente na atração cultural (ver Figura 4), sobretudo, de natureza folclórica, uma vez que tem diminuído, nos últimos anos, o investimento no entretenimento noturno da cidade. Assim, a realização de eventos culturais e artísticos é uma proposta que está de acordo com os princípios da Economia Criativa (Cruz, 2019). A sua diversidade permitiria captar públicos com interesses divergentes. Contudo, isto não invalidaria a necessidade de divulgação contínua destes empreendimentos culturais, artísticos e patrimoniais. Por outro lado, é necessário resolver a questão da insegurança pública, de acordo com Edlane Paiva, enquanto Jailde Melo acrescenta a necessidade da presença do Governo do Estado, com uma receção de informação turística sobre o estado do RN, como existiu no passado.

Figura 3: Divulgação do Centro de Turismo

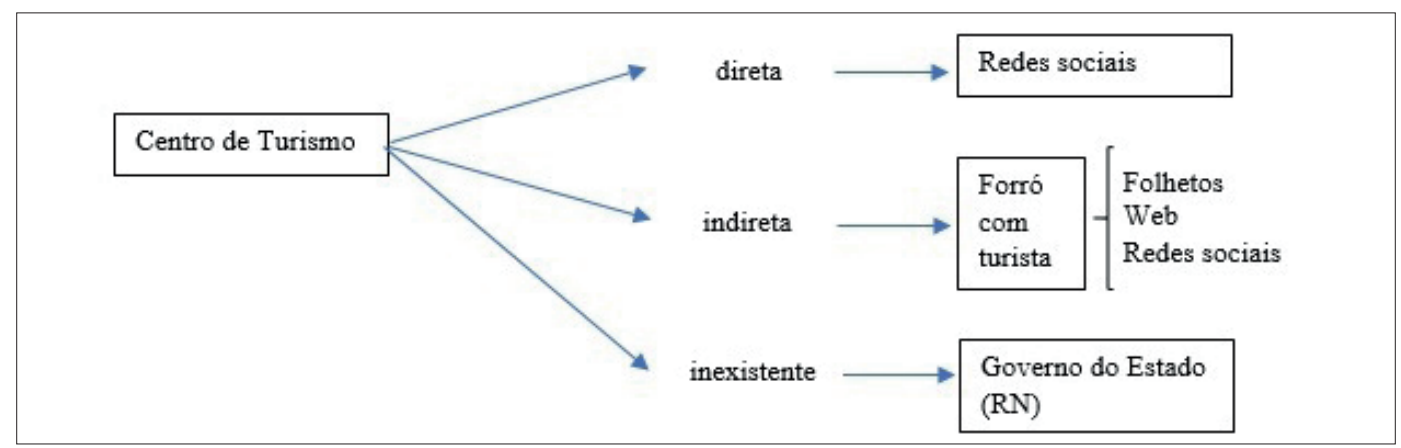

Fonte: Elaboração própria. 
Figura 4: Principais atividades no Centro de Turismo

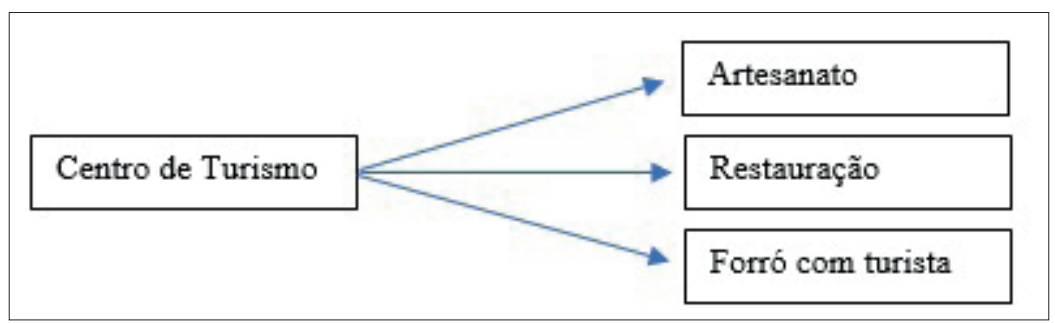

Fonte: Elaboração própria.

$\mathrm{Na}$ perspetiva destes entrevistados, os turistas apreciam a estrutura neoclássica do Centro de Turismo e a sua boa manutenção (Francisco Albuquerque). Edlane Paiva e Jailde Melo destacam ainda o acolhimento enquanto Raquel Medeiros critica o fato do turista nem sempre valorizar o artesanato, uma vez que o procura negociar por valores inferiores. Jailde Melo acrescenta que se trata sobretudo de turistas que vêm de São Paulo, Rio de Janeiro e do Rio Grande do Sul. Já estrangeiros - à exceção de portugueses, argentinos, uruguaios, paraguaios e bolivianos - são poucos os que visitam o Centro de Turismo. Nos fins-de-semana prolongados aparecem também os turistas de estados vizinhos, nomeadamente das cidades de Recife e João Pessoa. Aqui, percebemos os estereótipos dos empresários e vendedores em relação aos turistas (Pereiro, 2009), que os distinguem em função da sua origem, bem como sobre os seus comportamentos quando visitam o local. Acresce que acabam por valorizar no turista sobretudo o aspeto humano enquanto o interesse sobre o património cultural não é tão notado.

Sobre a relação com as agências de viagens e de turismo recetivo, Raquel Medeiros refere que são as agências de viagens e de turismo recetivo como CVC, Potiguar Turismo, Marazul Receptivo, Anauê e algumas outras vans que transportam os turistas para o Centro de Turismo e que informam um pouco da sua história. No entanto, Francisco Albuquerque salienta a parceria da ASSECTUR com a CVC para incluir o Centro de Turismo no city tour, serviço esse prestado pela Agência Potiguar. No entanto, estes entrevistados criticam o tempo de permanência dado aos turistas pelas empresas de viagens e de turismo recetivo. Como afirma Edlane Paiva: "são só [...] 40 minutos. Então, o pessoal reclama muito... [...] não dá tempo [para] comprar nada”.

A inclusão do Centro de Turismo no city tour leva-nos a concluir que estamos perante turistas de inspiração cultural, na expressão de Jansen-Verbeke (1997), uma vez que tratando-se de turistas atraídos pelo segmento sol e mar, não deixam de querer conhecer o seu património cultural - sobretudo artesanal -, ainda que na modalidade de turismo de massa.

Quanto à relação com os poderes públicos, os entrevistados entendem que o Governo do Estado deveria participar na divulgação do Centro de Turismo, por se tratar de património do Estado. A própria imagem do Centro de Turismo está ausente do material publicitário deste órgão político relativamente ao património cultural do Estado. De igual modo, a ausência do Governo do Estado neste espaço histórico e patrimonial, é notado por Edlane Paiva que acrescenta ainda a falta de folhetos turísticos informativos e de um espaço de informação turística.

\subsubsection{Representações sociais dos turistas}

A experiência turística na cidade de Natal (ver Figura 5) é comentada pela turista 2 como bastante agradável com praias "maravilhosas, paradisíacas, limpas" e um povo "muito acolhedor, muito solícito". Manifesta ainda ter apreciado a comida e os restaurantes Camarões, Mangai e Paprika, este último com transfer. Porém, um dos aspetos negativos que aponta diz respeito à inexistência de informações - ao contrário de todas as cidades que visitou - sobre o centro histórico, uma vez que gostaria de ter conhecido a arte sacra e as igrejas. Também, as turistas 3 e 4 confessaram ter gostado muito da cidade. Todavia, acrescentam não conhecer o seu centro histórico, a não ser a partir do tour panorâmico sobre a cidade. A turista 1, residente em Londrina (Paraná), destaca, por seu lado, a insegurança na cidade porque lhe dizem que "é perigoso, perigoso, pode ter assalto. Pode acontecer alguma coisa com vocês, vocês são turistas...". Daí que os turistas demonstrem relativamente à experiência turística os seus estereótipos (Pereiro, 2009). As praias, o povo, a gastronomia são esses elementos (estereótipos) que a experiência turística vem confirmar (ou infirmar). 
Figura 5: Qualidades da cidade de Natal, reconhecidas pelos turistas

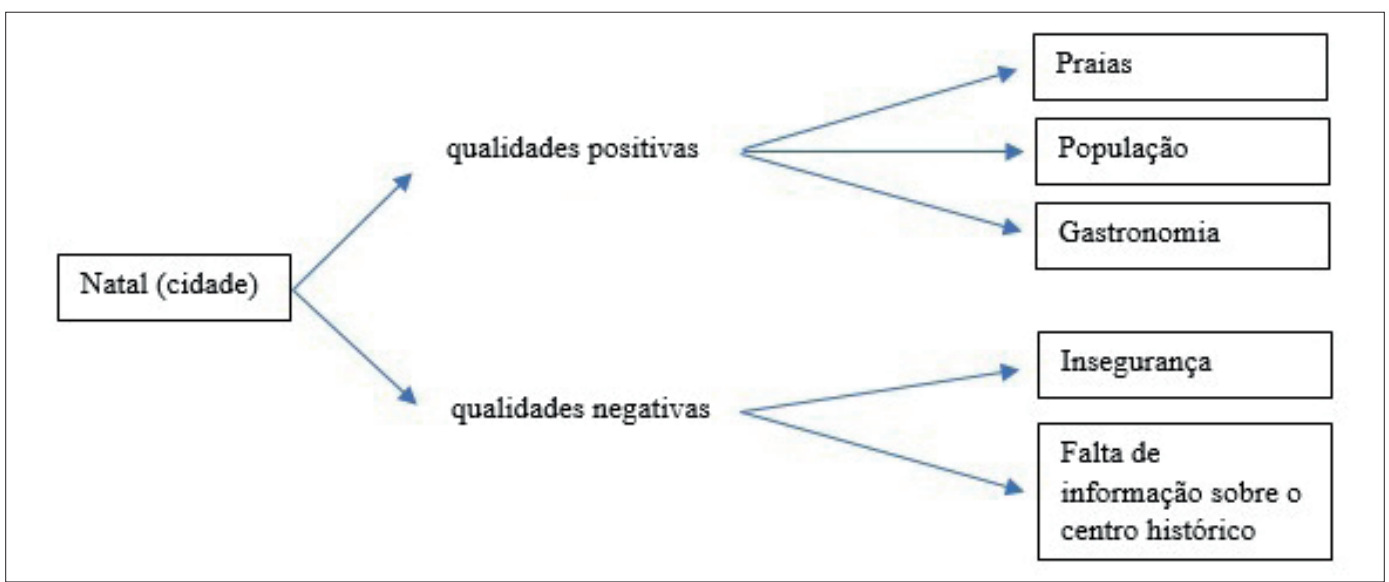

Fonte: Elaboração própria.

Sobre o roteiro turístico, em Natal (ver Figura 6), a turista 1 refere que contratou em Londrina (Paraná), onde reside, o city tour. Os pontos principais do seu trajeto foram: Cajueiro, em Pirangi, orla de Parnamirim e o Centro de Turismo. No Forte dos Reis Magos passaram sem parar. De carro, deslocou-se à Praia de Pipa e à Praia do Amor e, em Natal, visitou algumas igrejas. O turista 2 referiu ter contratado, no próprio hotel em que se encontrava hospedado, o city tour. A turista 3 possui uma agência de viagens em Agrestina (Pernambuco) e adotou o seguinte roteiro: Cajueiro de Pirangi, passeio de buggy, Aquário de Natal e "Forró com turista" no Centro de Turismo. Confirmamos que no trajeto do city tour, apenas o Centro de Turismo é contemplado com uma paragem de 30 a 40 minutos. No trajeto pelo centro histórico não há qualquer outra paragem. Quanto ao Cajueiro de Pirangi - onde se realiza uma feira permanente de artesanato -, o mesmo possui relevância ao nível do património natural. Os outros pontos de visita inserem-se na dinâmica do turismo de sol e mar. Assim, à falta de informação sobre o centro histórico de Natal e à falta "aparente" de interesse, na maioria dos turistas entrevistados, em o visitar, a não ser no contexto do city tour, dá-se um consumo expresso e maximizante da cultura.

Figura 6: Principais paragens na cidade de Natal (city tour)

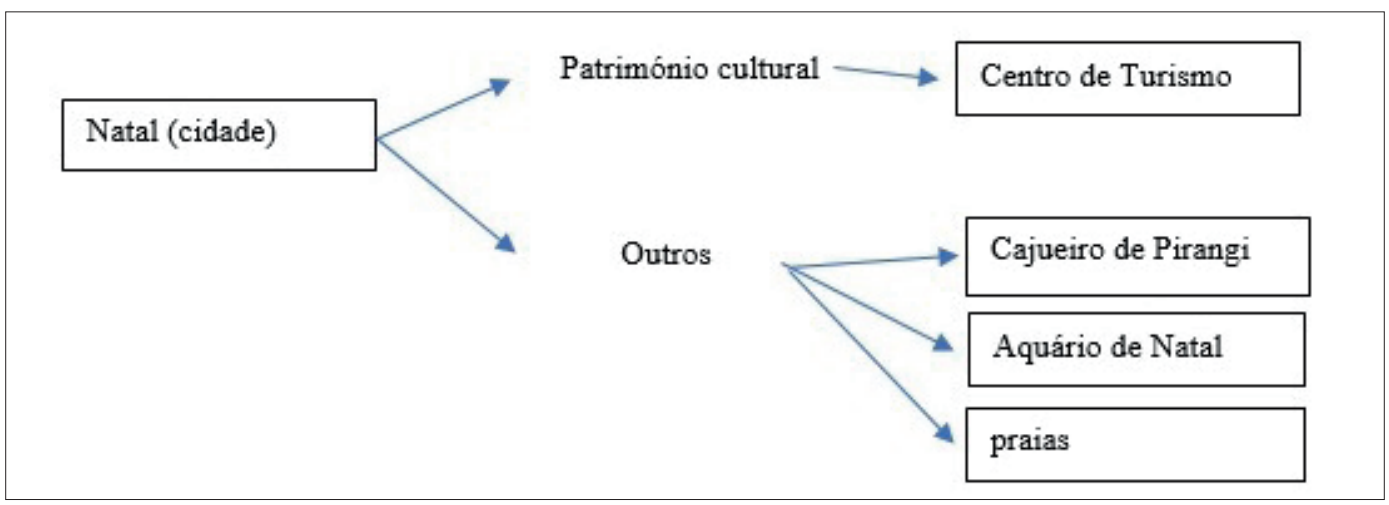

Fonte: Elaboração própria.

Sobre o Centro de Turismo (ver Figura 7), todos os turistas entrevistados salientam a organização, a hospitalidade e destacam ainda os preços praticados (turista 1), a existência de artesanato variado (turista 2 ) e a conjugação do artesanato com o prédio histórico (turista 3). Por isso, todos 
são da opinião que recomendariam a sua visita. No entanto, a turista 1 aponta, em relação às acessibilidades, a necessidade de "colocar mais uns degraus na entrada". Por outro lado, a turista 1 é da opinião que que deveriam ser organizados mais eventos no Centro de Turismo para ter mais público. Assim, nomeia possíveis eventos como "um festival de cachaça, um festival do licor, [...] um festival de dança, um festival de música". Quanto ao "Forró com turista", os turistas 1 e 2 nunca participaram, enquanto a turista 3 comenta: "Adorei! Super animado! Super cultural! É mostra da cultura nordestina, não só a de Natal... Uma forma belíssima para turistas de qualquer lugar que venha pra cá”.

Figura 7: Qualidades do Centro de Turismo, reconhecidas pelos turistas

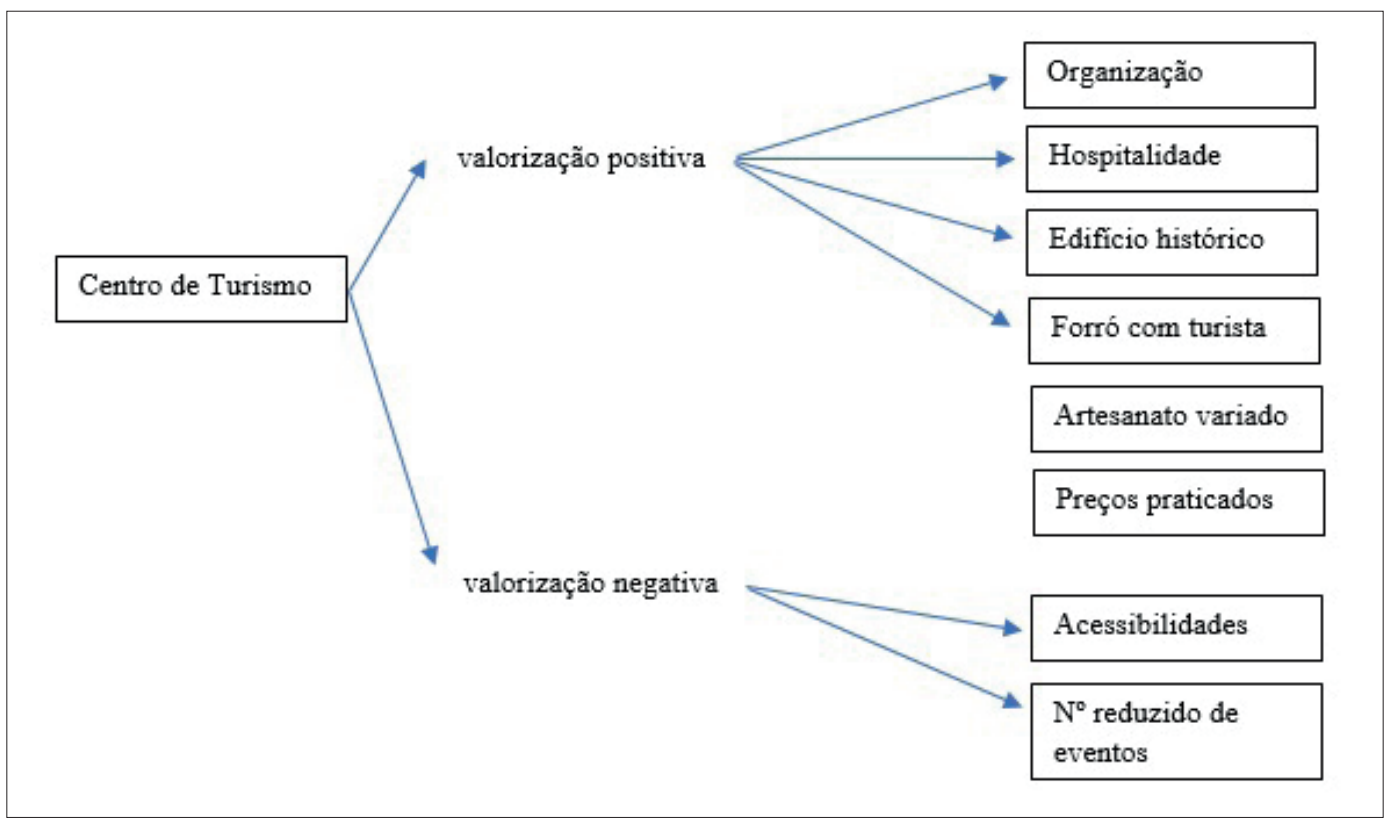

Fonte: Elaboração própria.

Seja visto como um exemplo da memória coletiva, seja como património da humanidade, o Centro de Turismo é um bom exemplo da oferta cultural, nomeadamente, ao nível do artesanato que permite a este espaço de interesse nacional e estadual estar aberto ao público e ser encarado como um exemplo da cultura como recurso (Yúdice, 2004), ao possibilitar a criação de emprego e crescimento económico.

\subsubsection{Representações sociais e perceções das autoridades públicas}

Christiane Alecrim, Secretária de Turismo da Prefeitura de Natal, considera que o Centro de Turismo está bem conservado enquanto Manuel Gaspar Júnior, Secretário do Turismo do Estado do Rio Grande do Norte, conclui que este poderia estar em melhor estado se não fossem as restrições financeiras.

Quanto às políticas públicas para o segmento do turismo cultural (ver Figura 8), a Secretária de Turismo de Natal relata que as principais ações são concertadas com a Secretaria Municipal da Cultura como o Carnaval, as festas juninas e as outras festas populares. Já Manuel Gaspar Júnior alude à inauguração de equipamentos culturais como o Complexo Cultural da Rampa, no bairro Santos Reis, em 2018, voltado para o envolvimento de Natal na Segunda Guerra Mundial (1939-1945) e a história da aviação a partir da década de 1920, com a chegada dos hidroaviões franceses. Outra ação do Estado planeada é a restauração da Fortaleza dos Reis Magos, a funcionar em condições precárias. Quanto ao centro histórico de Natal, invoca o início da requalificação das treze praças, a revitalização das fachadas de prédios qualificados do bairro da Ribeira e a reforma do Teatro Alberto Maranhão e da Escola de Dança. 
Figura 8: Turismo cultural, em Natal

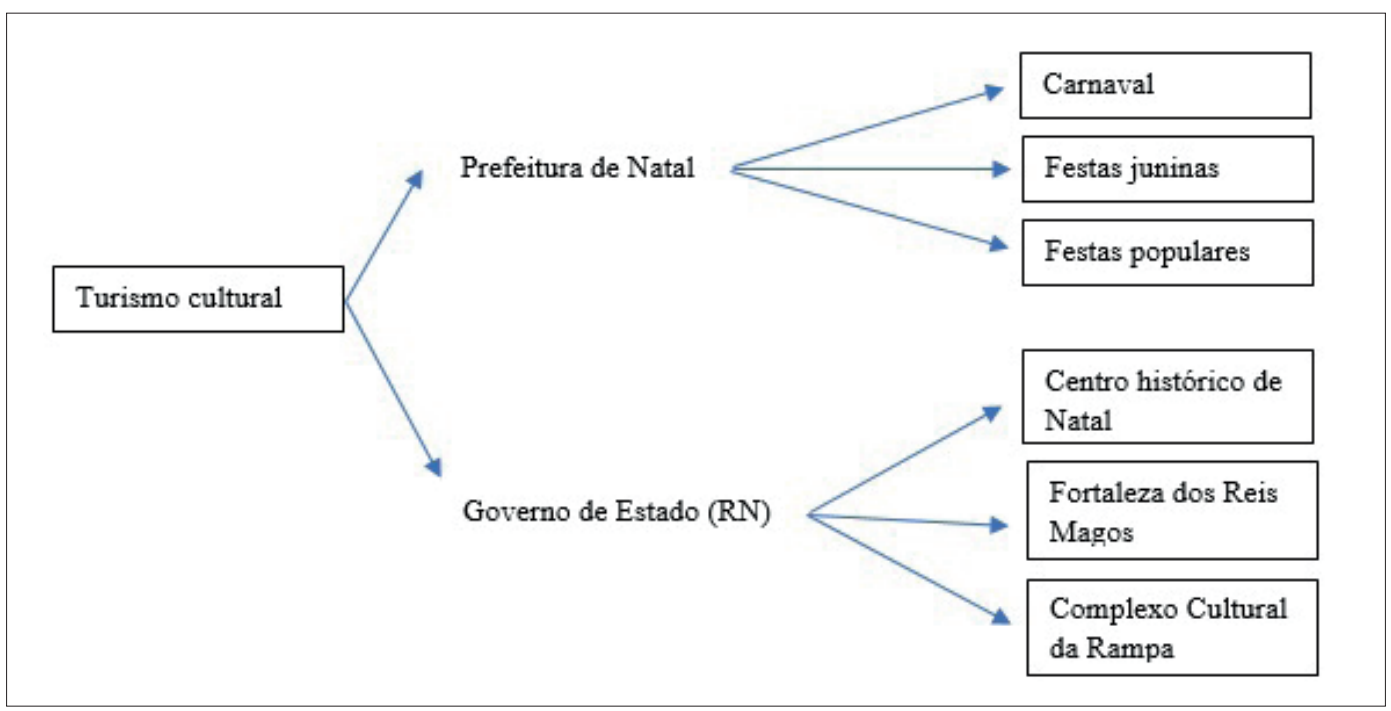

Fonte: Elaboração própria.

Sobre a consolidação do turismo, ambos os secretários concordam ser importante e fundamental o estabelecimento de parcerias entre o público e o privado e, nomeadamente, com as agências de viagens e de turismo recetivo, a Associação Brasileira da Indústria de Hotéis do Rio Grande do Norte e Natal Convention Bureau que se dedica à promoção do desenvolvimento do Turismo de Eventos e Negócios, em Natal. Contudo, o Secretário de Turismo do Estado entende que os roteiros de turismo cultural, em que se inclui o Centro de Turismo, são da responsabilidade das agências de turismo recetivo.

O turismo cultural é um dos segmentos reconhecidos no Plano Estratégico e de Marketing Turístico (2017-2032), do Governo do Estado, tendo por objetivo manter o turista mais tempo no RN. Para o desenvolvimento deste segmento, cabe referir que uma das obrigações da ASSECTUR, é que o artesanato vendido no Centro de Turismo tenha $70 \%$ de origem no próprio Estado. Cabe ainda mencionar o apoio à realização no Estado do Rio Grande do Norte de festivais de cinema, Fest Bossa \& Jazz e festivais gastronómicos. Em relação à segurança, a Secretaria do Turismo do Estado em parceria com a Secretaria de Segurança tem procurado o reforço da segurança dos principais equipamentos turísticos, uma vez que o turismo é considerado o principal vetor da economia do Estado.

O Plano Estratégico do turismo do Governo de Estado reconhece a necessidade de diversificar o turismo no Estado e, por isso, integra ações de promoção de turismo cultural. Nesse sentido, procura criar, recuperar, restaurar e promover património cultural, em diferentes municípios do Estado. Porém, há o reconhecimento da falta de investimento no Centro de Turismo devido a limitações financeiras. Acreditamos contudo que a dinamização do segmento de turismo cultural não é prioritário para o referido Governo, uma vez que o centro histórico de Natal, apesar de qualificado de interesse nacional pelo Iphan, em 2010, possui um elevado nível de degradação, a qual já implicou o encerramento de diversos imóveis, alguns deles há mais de uma década. E, apesar da recuperação iniciada, a morosidade da conclusão das obras inviabilizam a visita ou a exploração económica por parte das agências de turismo recetivo e outros agentes turísticos.

\section{Considerações finais}

O Centro de Turismo é um imóvel classificado de interesse estadual e integra o centro histórico, o qual foi classificado, em 2010, pelo Iphan (2019) de interesse nacional (Brasil). A propriedade é estadual $(\mathrm{RN})$ e a gestão pertence à ASSECTUR constituída pelos empresários com empreendimentos no referido imóvel, em que sobressai como setor dominante o artesanato. Em 2018, recebeu 114.367 visitantes 
canalizados pelas agências de viagens e de turismo recetivo e táxis. Esta visita deu-se para a maioria dos visitantes, no seio do city tour e teve, em média, uma duração de 30 a 40 minutos. Fora desse circuito panorâmico, o Forró com turista, nas noites de quinta-feira, capta turistas fora desses circuitos. Trata-se ainda do imóvel com mais visitantes do centro histórico, uma vez que existem vários imóveis fechados a aguardar a sua requalificação urbanística. Este imóvel beneficia ainda de se localizar na cidade de Natal que se constitui como destino privilegiado no segmento de sol e mar. Esta cidade está dotada de uma ampla infraestrutura em termos de alojamento e restauração.

O presente estudo de caso não é passível de generalização, dada a sua natureza qualitativa. Acresce ainda que por se tratar de um estudo exploratório, não podemos considerar encerrada a investigação, uma vez que as conclusões obtidas agora permitem outros encaminhamentos com vista ao tratamento exaustivo do objeto de estudo. Assim, apesar das suas limitações, acreditamos que é possível, a partir dele, propor um modelo de análise passível de ser aplicado a novos estudos ou ainda a outros casos, tendo em vista a sua comparabilidade. Desse modo, propomos que essa análise e respetivo modelo (ver Figura 9) assentem em categorias - cultura, turismo e políticas públicas - e subcategorias - património cultural, redes, infraestruturas, eventos.

Por conseguinte, através do modelo proposto, verificamos que há uma interdependência entre as diferentes categorias. Na pesquisa realizada, compreendemos que o turismo cultural nos centros históricos depende da inter-relação entre Cultura, Turismo e Políticas públicas. Já as subcategorias do património cultural e dos eventos devem ser tratadas dentro da 'Cultura' enquanto que na de 'Turismo' observamos as subcategorias 'Infraestruturas' e 'Redes'. Por fim, podemos identificar em cada categoria - e subcategoria -, as respetivas potencialidades e fragilidades do caso em estudo.

\section{Figura 9: Modelo de Turismo cultural, a partir de centros históricos}

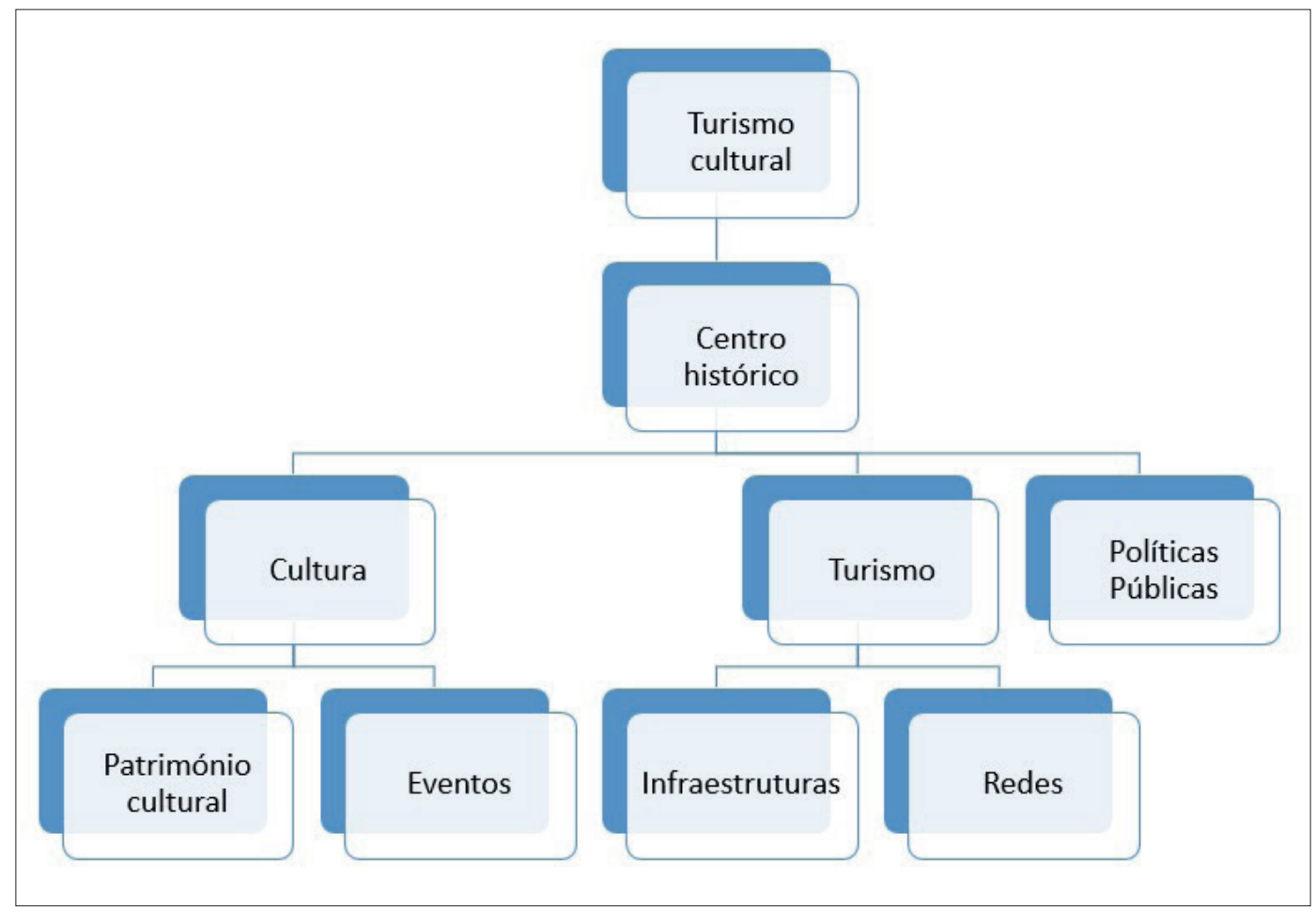

Fonte: Elaboração própria.

Na identificação das referidas potencialidades e fragilidades, começamos por verificar que na categoria 'Cultura', onde incluímos o 'Património cultural' e os 'Eventos', partindo da conceção de 
cultura como recurso (Yúdice, 2004) e da economia criativa (Cruz, 2016) constituem-se aqui como potencialidades:

- Classificação de interesse estadual do Centro de Turismo;

- Classificação de interesse nacional do centro histórico (Iphan);

- Entrega da gestão do Centro de Turismo à ASSECTUR;

- Inclusão do Centro de Turismo no city tour;

- Ocupação do Centro de Turismo com lojas de artesanato;

- Organização do Forró com turista, no Centro de Turismo;

- Requalificação em curso dos imóveis degradados, no centro histórico;

- Fundação histórica de Natal, em 1599.

Quanto às fragilidades identificadas nesta categoria:

- Estado de degradação de muitos imóveis do centro histórico;

- Tendência à perpetuação do encerramento dos imóveis degradados no centro histórico;

- Falta de lugares de estacionamento próximo do centro histórico, para exploração do city tour;

- Divulgação fraca do património cultural, por parte dos poderes públicos;

- Número reduzido de eventos culturais no Centro de Turismo e no centro histórico;

- Variedade reduzida de eventos culturais no Centro de Turismo e no centro histórico.

Quanto à categoria 'Turismo”, onde incluímos as subcategorias 'Redes' e 'Infraestruturas' identificamos como potencialidades:

- Elevado número de turistas do segmento de sol e mar;

- População hospitaleira;

- Rede ampla e diversificada de hotéis e restaurantes na cidade;

- Rede de equipamentos de diversão e lazer noturnos na cidade;

- Aeroporto internacional de Natal;

- Rede de agências de viagens nacionais e locais e de turismo receptivo.

Constituem fragilidades, nesta categoria:

- Reduzido número de turistas do segmento cultural;

- Reduzida variedade tipológica de turistas culturais (Jansen-Verbeke, 1997);

- Ausência de uma loja do Estado do RN para divulgação turística no Centro de Turismo;

- Reduzida divulgação da ASSECTUR das atividades culturais desenvolvidas no Centro de Turismo, à exceção do Forró com Turista;

- Fraca ou nenhuma divulgação de "Natal" como destino cultural.

Quanto à categoria 'Políticas públicas', identificamos as seguintes potencialidades:

- Reconhecimento e delimitação de um centro histórico;

- Criação de infraestruturas de valorização do património cultural;

- Organização e apoio de grandes eventos;

- Aprovação do Plano Estratégico e de Marketing de Turismo (2017-2032).

Nesta categoria são fragilidades:

- Reduzido investimento público na Cultura, eventos e Património cultural;

- Baixa prioridade das políticas culturais comparativamente às políticas económicas;

- Apoio reduzido à formação de públicos culturais;

- Sensação de insegurança urbana generalizada;

- Localização do centro histórico junto de áreas urbanas degradadas e ocupadas por populações marginalizadas socialmente;

- Aparente desinteresse da população em relação à 'memória coletiva".

Cabe ainda ressaltar que a aprovação do Plano Estratégico e de Marketing de Turismo (2017-2032) define a necessidade de dar atenção a outros segmentos como o de turismo cultural de forma ao turista permanecer mais tempo na cidade. Por fim, se a preservação e a promoção da cultura são 
da responsabilidade do Estado, também o é no que respeita ao turismo cultural, pelo que não se pode demitir das causas que impedem a exploração do centro histórico pelas agências de viagens e de turismo recetivo. O Estado pode apoiar, organizar e promover igualmente eventos no centro histórico de modo a aumentar a sua visibilidade quer para a população local, quer para aumentar o número de turistas culturais. Os próprios agentes turísticos não deixarão de corresponder com a oferta de serviços para estes espaços. Para isso, o Governo precisa demonstrar que cultura, património e turismo cultural são prioridades na política do Estado. Mas passa igualmente pela educação da própria população local que deve, em primeiro lugar, aprender a valorizar o seu património e a sua cultura, assim como a usufruir do centro histórico com segurança e com apelos ao nível de eventos culturais, artísticos e patrimoniais.

A triangulação da Cultura, Turismo e Políticas Públicas implica a criação de canais de diálogo e entendimento entre agentes económicos, agentes culturais, a sociedade civil e as autoridades públicas nacionais, estaduais e locais. Apenas desta forma é possível, no nosso entendimento, valorizar a cultura como recurso e gerar mais empregos, manifestações culturais e desenvolvimento humano e sustentável, para além de contribuir para a valorização e preservação da memória coletiva e do património cultural.

A título de encerramento, acreditamos ser possível aprofundar o modelo aqui proposto de modo a fomentar os estudos sobre o turismo cultural nos centros históricos e a comparabilidade de casos, tendo em vista subsidiar a elaboração de planos de desenvolvimento turístico, no domínio cultural.

\section{Bibliografía}

Almeida, J. F. y Pinto, J. M. 1995. A investigação nas Ciências Sociais: estudo elaborado no gabinete de investigações sociais. Lisboa: Presença.

Bardin, L. 2008. Análise de conteúdo. Lisboa: Edições 70.

Bourdieu, P. 1989. O poder simbólico. Lisboa: Difel.

Bourdieu, P. 2007. A distinção: crítica social do julgamento. São Paulo: Edusp; Porto Alegre/ RS: Zouk. Brasil 1988. Constituição da República Federativa do Brasil. Brasília: Senado Federal, Centro Gráfico.

Chuva, M. y Nogueira, A. G. R. (Orgs.) 2012. Patrimônio cultural: políticas e perspectivas de preservação no Brasil. Rio de Janeiro: Mauad X.

Costa, A. y Amaral, P. 2014. Centro histórico de Natal: guia para turistas e moradores. Natal: IFRN.

Creswell, J. W. 2009. Research design: Qualitative, Quantitative, and Mixed Methods Approaches. Los Angeles; London; New Delhi; Singapore: Sage.

Cruz, F. M. R. 2011. A tematização nos espaços públicos. Estudo de caso nas cidades de Porto, Vila Nova de Gaia e Barcelona. Uma análise sobre a qualidade e estrutura dos espaços públicos (Tesis doctoral). Universidade do Porto. Disponible en: https://www.researchgate.net/publication/283325947_A_tematizacao_nos_espacos_publicos_estudo_de_caso_nas_cidades_de_Porto_Vila_Nova_de_Gaia_e_Barcelona_Uma_analise_sobre_a_qualidade_e_estrutura_dos_espacos_publicos (15/01/2020)

Cruz, F. M. R. 2016. Ambiente Criativo: estudo de caso na cidade de Natal/RN. Natal/RN: EDUFRN.

Cruz, F. M. R. 2018. "Turismo y Carnaval: estudio sobre los impactos en el patrimonio cultural de la ciudad de Natal/RN (Brasil)". Revista Andaluza de Antropología, 15: 3-21. Disponible en: http:// www.revistaandaluzadeantropologia.org/index.php?page=rocha-da-cruz-fernando-manuel-turismo-y-carnaval-estudios-sobre-los-impactos-en-el-patrimonio-cultural-de-la-ciudad-de-natal-rn-brasil $(15 / 01 / 2020)$

Cruz, F. M. R. 2019a. "La informalidad en la industria cultural de la música y la promoción de la economía creativa en la ciudad de Natal/RN (Brasil)". Aposta. Revista de Ciencias Sociales, 81: 54-68. Disponible en: http://apostadigital.com/revistav3/hemeroteca/fmrcruz.pdf (15/01/2020)

Cruz, F. M. R. 2019b. "Problematização, princípios, ações e desafios da Incubadora Cultural da UFRN". En Alves, T. A. et al (Orgs), Plano de cultura da UFRN: percursos, ações e resultados: 2015 - 2019. Natal/ RN: EDUFRN. Disponible en: https://repositorio.ufrn.br/jspui/handle/123456789/27115 (15/01/2020)

Dümcke, C. y Gnedovsky, M. 2013. The Social and Economic Value of Cultural Heritage: literature review. EENC Paper.

Eagleton, T. 2003. A ideia de cultura. Lisboa: Temas e Debates.

Figueroa, J. 2017. "O que é turismo receptivo e como organizá-lo?". En Belatur. Disponible en: https:// blog.belaturismo.com/o-que-e-turismo-receptivo-e-como-organiza-lo/ (15/01/2020)

Geertz, C. 2008. A interpretação das culturas. Rio de Janeiro: LTC.

Halbwachs, M. 1990. A memória coletiva. São Paulo: Vértice.

Halbwachs, M. 1994. Les cadres sociaux de la mémoire. Paris: Albin Michel. 
Holdaway, S. 2000. "Theory and method in qualitative research". En Burton, D. (Ed), Research training for social scientists: a handbook for postgraduate (pp. 156-166). London; Thousand Oaks; New Delhi: Sage.

Ibge 2019. Natal. Disponible en: https://cidades.ibge.gov.br/brasil/rn/natal/panorama (15/01/2020)

Ipdc 2018. Perfil do turista do RN: alta estação 2018. Natal: Fecomercio RN.

Iphan 2018. Monumentos e Espaços Públicos Tombados - Natal (RN). Disponible en: http://portal.iphan. gov.br/pagina/detalhes/1458/ (15/01/2020)

Iphan 2018. Monumentos e Espaços Públicos Tombados - Natal (RN). Disponible en: http://portal.iphan. gov.br/pagina/detalhes/1458/ (15/01/2020)

Iphan 2019. Centro histórico de Natal ganha título de patrimônio cultural do Brasil. Disponible en: http://portal.iphan.gov.br/noticias/detalhes/3163 (15/01/2020)

Iphan, 2010. Centro histórico de Natal ganha título de patrimônio cultural do Brasil. Disponible en: http:// portal.iphan.gov.br/rj/noticias/detalhes/3163/centro-historico-de-natal-ganha-titulo-de-patrimonio-cultural-do-brasil (15/01/2020)

Jansen-Verbeke, M. 1997. "Urban tourism. Managing resources and visitors". En Pigram, J. J. y Wahab, S. (Eds), Tourism, development and growth: The Challenge of Sustainability (237-257). Routledge, London.

Köhler, A. F. y Durand, J. C. G. 2007. "Turismo cultural: conceituação, fontes de crescimento e tendências". Turismo - Visão e Ação, 9(2): 185-198.

Maffesoli, M. 2012. O tempo retorna: formas elementares da pós-modernidade. Rio de Janeiro: Forense Universitária.

Martins, J. C. O. 2013. "Tempo livre, ócio e lazer: sobre palavras, conceitos e experiências". En Martins, J. C. y Baptista, M. M. (Orgs), O ócio nas culturas contemporâneas - teorias e novas perspectivas em investigação (pp. 11-22). Coimbra: Gracio.

Marujo, N., Serra, J. y Borges, M. R. 2013. "Turismo cultural em cidades históricas: a cidade de Évora e as motivações do turista cultural". TuryDes: Revista de investigación en turismo y desarrollo local, 6(14): 1-10. Disponible en: http://www.eumed.net/rev/turydes/14/turismo-cultural.html (15/01/2020)

Mckercher, B. y Du Cros, H. 2003. "Testing a cultural tourism typology". The International Journal of Tourism Research, 5(1): 45-58.

Melo, A. y Cardozo, P. F. 2015. "Patrimônio, turismo cultural e educação patrimonial". Educ. Soc., 36(133): 1059-1075. Disponible en: http://www.scielo.br/pdf/es/v36n133/1678-4626-es-36-133-01059. $\operatorname{pdf}(15 / 01 / 2020)$

Morais, I. A. L. 2012. "Turistificação do Patrimônio e dos Museus". En Anais da $28^{a}$ Reunião Brasileira de Antropologia. São Paulo. Disponible en: https://www.academia.edu/34373521/ TURISTIFICA\%C3\%87\%C3\%83O_DO_PATRIM\%C3\%94NIO_E_DOS_MUSEUS (15/01/2020)

Natal 2008. Natal: história, cultura e turismo. Natal: DIPE - SEMURB. Disponible en: https://www. natal.rn.gov.br/semurb/paginas/ctd-113.html (15/01/2020)

Nogueira, A. G. R. 2014. "O campo do patrimônio cultural e a história: itinerários conceituais e práticas de preservação”. Antíteses, 7(14): 45-67. Disponible en: http://www.uel.br/revistas/uel/index.php/ antiteses/article/view/19969 (15/01/2020)

Oliveira, C. F. 2016. A cidade de Goiás como patrimônio cultural mundial: descompassos entre teorias, discursos e práticas de preservação (Tesis doctoral). FAUUSP. Disponible en: https://www.teses.usp. br/teses/disponiveis/16/16133/tde-20122016-142028/publico/carolinafidalgo.pdf (15/01/2020)

Oosterbeek, L. 2015. "Revisitando Antígona: o património cultural na fronteira da globalização". En Campos, J. B., Preve, D. R. y Souza, I. F. (Orgs), Patrimônio cultural, direito e meio ambiente: um debate sobre a globalização, cidadania e sustentabilidade (pp. 13-29). Curitiba: Multideia. Disponible en: http://portal.iphan.gov.br/uploads/publicacao/texto_especializado.pdf (15/01/2020)

Pereiro, X. 2003. "Patrimonialização e transformação das identidades culturais". En Portela, J. y Caldas, J. C. (Coords.), Portugal Chão (pp. 231-247). Oeiras: Celta editora.

Pereiro, X. 2009. Turismo Cultural. Uma visão antropológica. Tenerife (Espanha): ACA y PASOS, RTPC.

Prodanov, C. C. y Freitas, E. C. 2013 Metodologia do trabalho científico: métodos e técnicas da pesquisa e do trabalho acadêmico. Novo Hamburgo: Feevale.

Rada, A. D. 2005. Etnografía y Técnicas de investigación antropológica. Madrid: Universidad Nacional de Educación a Distancia.

Richards, G. 2007. Cultural Tourism: global and local perspectives. New York: THHP.

Richards, G. 2009. The impact of culture on tourism. Paris: OECD. 
Rocha, A. R. 2018. "Mesmo com insegurança, Turismo do RN cresceu 3,8\%". En Panrotas. Disponible en: https://www.panrotas.com.br/noticia-turismo/destinos/2018/01/mesmo-com-inseguranca-turismo-do-rn-cresceu-38-_152377.html (15/01/2020)

Romero, A. 1991. Metodologia de análise de conteúdo. Lisboa: Universidade Católica Portuguesa.

Silva, A. F. 2001. "Migração e crescimento urbano: uma reflexão sobre a cidade de Natal, Brasil". Scripta Nova, 94(74), 1 de agosto de 2001. Universidad de Barcelona. Disponible en: http://www.ub.edu/ geocrit/sn-94-74.htm (15/01/2020)

Sousa, R. P. M., Netto, C. X. A. y Oliveira, B. M. J. F. 2019. "A efetividade dos mecanismos de proteção do patrimônio cultural na preservação da memória coletiva”. InCID: R. Ci. Inf. e Doc., 9(2): 27-47. Disponible en: http://www.revistas.usp.br/incid/article/view/138351/148265 (15/01/2020)

Tamaso, I. 2005. "A expansão do patrimônio: novos olhares sobre velhos objetos, outros desafios... (Laudos culturais dos antropólogos inventariantes)”. Sociedade e Cultura, 8(2): 13-36.

Tribuna do Norte 2016. Centro de Turismo tem potencial sub-explorado. Disponible en:http://www. tribunadonorte.com.br/noticia/centro-de-turismo-tem-potencial-sub-explorado/357228 (15/01/2020)

Unesco 1972. Convenção para a Protecção do Patrimó nio Mundial, Cultural e Natural. Paris: UNESCO. Disponible en: https://whc.unesco.org/archive/convention-pt.pdf (15/01/2020)

Urry, J. y Larsen, J. 2011. The tourist gaze 3.0. Los Angeles, London, New Deli: Sage.

Williams, R. 2000. Cultura. Rio de Janeiro: Paz e Terra.

Yin, R. 2005. Estudo de caso: planejamento e métodos. Porto Alegre: Bookman.

Yúdice, G. 2004. A conveniência da cultura: usos da cultura na era global. Belo Horizonte: Editora UFMG.

\section{Notes}

Tombamento, na expressão brasileira.

Agência de turismo recetivo é uma agência local com funcionários e guias, também locais, que conhecem com propriedade o funcionamento de tudo o que diz respeito a esse lugar, pelo que o trabalho delas é justamente tornar tudo funcional e confortável (Figueroa, 2017).

Empresário do Marenosso Restaurante, Forró com turista e uma loja de artesanato no Centro de Turismo de Natal.

Artesã, empresária e presidente da ASSECTUR, no Centro de Turismo de Natal.

Ver https://www.forrocomturista.com.br/.

Vendedora de artesanato no Centro de Turismo de Natal.

Também chamados furgões ou carrinhas destinados ao transporte de passageiros.

Operadora de turismo na América Latina.

Artesã e empresária no Centro de Turismo de Natal. 